\title{
POLA DAN KEMAMPUAN PEMECAHAN MASALAH PESERTA DIDIK MELALUI PEMBELAJARAN FLIPPED CLASSROOM BERBASIS PROYEK
}

\author{
Ima Ismiati ${ }^{1)}$, Sarwi ${ }^{2)}$, Putut Marwoto2) \\ 1)Program Studi Pendidikan Fisika, Pascasarjana, Universitas Negeri Semarang, Semarang, Indonesia \\ 2)Jurusan Fisika, FMIPA, Universitas Negeri Semarang, Semarang, Indonesia \\ Corresponding author : Ima Ismiati \\ E-mail : ima.ismiati19@gmail.com
}

Diterima 22 Februari 2020, Disetujui 6 Maret 2020

\begin{abstract}
ABSTRAK
Penelitian ini bertujuan untuk mengetahui kemampuan pemecahan masalah dan pola pemecahan masalah berdasarkan tingkat pemecahan masalah peserta didik melalui pembelajaran flipped classroom berbasis proyek. Penelitian menggunakan rancangan quasi eksperimen dengan desain onegroup pretest-postest desaign. Penelitian dilaksanakan di SMAN 14 Semarang tahun ajaran 2019/2020 dengan subjek penelitian 65 peserta didik kelas XI MIPA. Sampel diperoleh melalui teknik purposive sampling. Teknik pengumpulan data dilakukan menggunakan tes dan wawancara. Analisis data kemampuan pemecahan masalah dilakukan secara deskriptif. Hasil menunjukkan bahwa Kemampuan pemecahan masalah peserta didik dalam pembelajaran flipped classroom berbasis proyek tergolong tinggi dengan jumlah peserta didik $57 \%$. Peserta didik memiliki pola pemecahan masalah yang berbedabeda berdasarkan tingkat pemecahan masalah. Peserta didik kategori sangat tinggi melakukan penyelesaian dengan membaca, memahami masalah, menganalisis, merencanakan strategi penyelesaian, menerapkan dan mengevaluasi seluruh solusi. Peserta didik kategori tinggi melakukan penyelesaian dengan membaca, memahami masalah, menganalisis, merencanakan strategi penyelesaian, menerapkan dan mengevaluasi solusi matematis. Peserta didik kategori rendah melakukan penyelesaian dengan membaca, memahami masalah, menganalisis, menentukan masalah.
\end{abstract}

Kata kunci: kemampuan pemecahan masalah; pola pemecahan masalah; flipped classroom berbasis proyek.

\begin{abstract}
This study aims to determine the ability of problem-solving and problem-solving patterns based on the level of problem-solving of students through project-based flipped classroom learning. The study used a quasi-experimental design with a one-group pretest-posttest village design. The study was conducted at SMAN 14 Semarang in the academic year 2019/2020 with the research subjects 65 students of class XI MIPA. Samples were obtained through a purposive sampling technique. Data collection techniques are done using tests and interviews. Data analysis of problem-solving ability is done descriptively. The results show that the students' problem-solving ability in project-based flipped classroom learning is relatively high with $57 \%$ of students. Students have different patterns of problem-solving based on the level of problem-solving. Very high category students complete the solution by reading, understanding the problem, analyzing, planning a settlement strategy, implementing and evaluating all solutions. High category students do the settlement by reading, understanding the problem, analyzing, planning a settlement strategy, implementing and evaluating mathematical solutions. Low category students do the settlement by reading, understanding the problem, analyzing, determining the problem.
\end{abstract}

Keywords: problem-solving skill; pattern of problem solving; project-based flipped classroom.

\section{PENDAHULUAN}

Pendidikan bermaksud membantu mengembangkan potensi-potensi yang dimiliki oleh peserta didik, yang menjadi tujuan utamanya adalah terjadinya proses belajar (Tirtaraharja \& Sulo, 2010). Sama halnya dalam pembelajaran fisika, bukan hanya memahami perhitungan matematisnya tetapi juga konsep dasar yang mendasari prosesnya (Nikat et al.,
2017). Peserta didik dituntut mampu memahami konsep-konsep fisika, prinsipprinsip, mampu memecahkan permasalahan yang dihadapi dan mengkomunikasikannya dengan tepat.

Peserta didik menganggap pelajaran fisika sulit, terlalu banyak formula, hukum, teoritis, dan konten tidak mudah dipahami (Erinosho, 2013). Menurut Sattizahn et al., 
(2015) kesulitan peserta didik dalam pelajaran sains berhubungan dengan kesalahpahaman tentang konsep ilmiah dan juga persepsinya tentang materi tersebut. Peserta didik pun memiliki kemampuan pemecahan masalah fisika yang cenderung rendah (Purnamasari et al., 2017; Putra et al., 2018; Purwanto et al., 2017).

Keberhasilan peserta didik dalam pemecahkan masalah fisika tidak hanya bergantung dalam mengetahui konsep fisika, tetapi juga membangun hubungan antara semua informasi dan konsep permasalahan (Ince, 2018). kemampuan pemecahan masalah merupakan kemampuan yang berfokus pada analisis dalam proses pemilihan konsepkonsep yang diperlukan peserta didik untuk memecahkan suatu permasalahan (Rivai et al., 2017). Kemampuan tersebut dapat memudahkan peserta didik melihat masalah fisika dari beberapa konteks yang berbeda dalam penyelesaiannya, sehingga pembelajaran lebih bermakna (Mohotalla, 2016).

Ada beberapa langkah untuk menyelesaikan masalah. Menurut Alberida et al., (2018) pola pemecahan masalah untuk sains terdiri dari pendahuluan, observasi, masalah awal, pengumpulan data, pengorganisasian data, analisis/generalisasi data, dan komunikasi. Anderson (2009) menyatakan bahwa pemecahan masalah merupakan keterampilan yang melibatkan proses menganalisis, menafsirkan, menalar, memprediksi, mengevaluasi dan merefleksikan. Lain halnya dengan Ge \& Land (2004) menyatakan proses utama untuk memecahkan masalah yaitu representasi masalah, membangun dan memilih solusi, membuat pembenaran, dan memonitor serta mengevaluasi tujuan-tujuan dan solusi-solusi.

Melihat pentingnya kemampuan pemecahan masalah bagi peserta didik, perlu adanya pembelajaran yang mendukung untuk mengembangkan kemampuan tersebut. Pembelajaran harus mampu membawa fenomena fisika menjadi sesuatu yang dapat diamati, dianalisis dan dapat secara langsung disimpulkan oleh peserta didik. Menurut Quint dan Condliffe (2018) pembelajaran berbasis proyek merupakan pendekatan yang memungkinkan peserta didik untuk mengembangkan kompetensi Abad ke-21. Inti pembelajaran ini untuk menghubungkan pengalaman peserta didik dengan kehidupan dan memprovokasi pemikirannya untuk memperoleh pengetahuan baru (Efstratia, 2014). Pembelajaran proyek memiliki efek positif terhadap hasil belajar (Chen \& Yang, 2019), meningkatkan pemecahan masalah dan keterampilan pengambilan keputusan peserta didik (Kaya et al., 2014).

Flipped classroom adalah pembelajaran yang berpusat pada peserta didik yang terdiri dari dua bagian dengan kegiatan pembelajaran interaktif selama pembelajaran dan pengajaran individu langsung pada komputer di luar jam pelajaran (Bishop \& Verleger, 2013). Goughan (2014) mengungkapkan bahwa terdapat beberapa keunggulan pada flipped classroom yaitu belajar aktif, sikap belajar yang membudidaya, penggunaan waktu kelas yang lebih menguntungkan dan menempatkan penekanan pada kemampuan belajar dan pemecahan masalah peserta didik. Nouri (2016) menyatakan bahwa sikap positif terhadap flipped classroom sangat berkorelasi dengan peningkatan motivasi, keterlibatan peserta didik. Selain itu, flipped classroom berpengaruh terhadap hasil belajar (Yulietri et al., 2015).

Deng (2018) menerapkan
pembelajaran kelas terbalik berbasis proyek. Berdasarkan hasil penelitiannya diperoleh informasi bahwa pembelajaran flipped classroom berbasis proyek dapat meningkatkan motivasi belajar dan merangsang peserta didik untuk berpartisipasi aktif di kelas. Selanjutnya, penelitian ini bertujuan untuk mengetahui kemampuan pemecahan masalah dan pola pemecahan masalah bedasarkan tingkat pemecahan masalah peserta didik melalui pembelajaran flipped classroom berbasis proyek.

\section{METODE PENELITIAN}

Penelitian ini menggunakan rancangan quasi eksperimen dengan desain one-group pretest-postest desaign. Variabel penelitian ini adalah kemampuan pemecahan masalah peserta didik. Penelitian dilaksanakan di SMAN 14 Semarang tahun ajaran 2019/2020 dengan subjek penelitian 65 peserta didik kelas XI MIPA. Sampel diperoleh melalui teknik purposive sampling.

Teknik pengumpulan data dilakukan menggunakan tes dan wawancara. Metode tes digunakan untuk memperoleh hasil kemampuan pemecahan masalah. Wawancara digunakan untuk memperoleh pola penyelesaian pemecahan masalah peserta didik. Teknik analisis data kemampuan pemecahan masalah dilakukan secara deskriptif. Penilaian kemampuan pemecahan masalah berdasarkan rubrik pemecahan masalah Doctor et al. (2016) yang telah di modifikasi yang ditunjukkan pada Tabel 1. 
Tabel 1. Rubrik Kemampuan Pemecahan Masalah

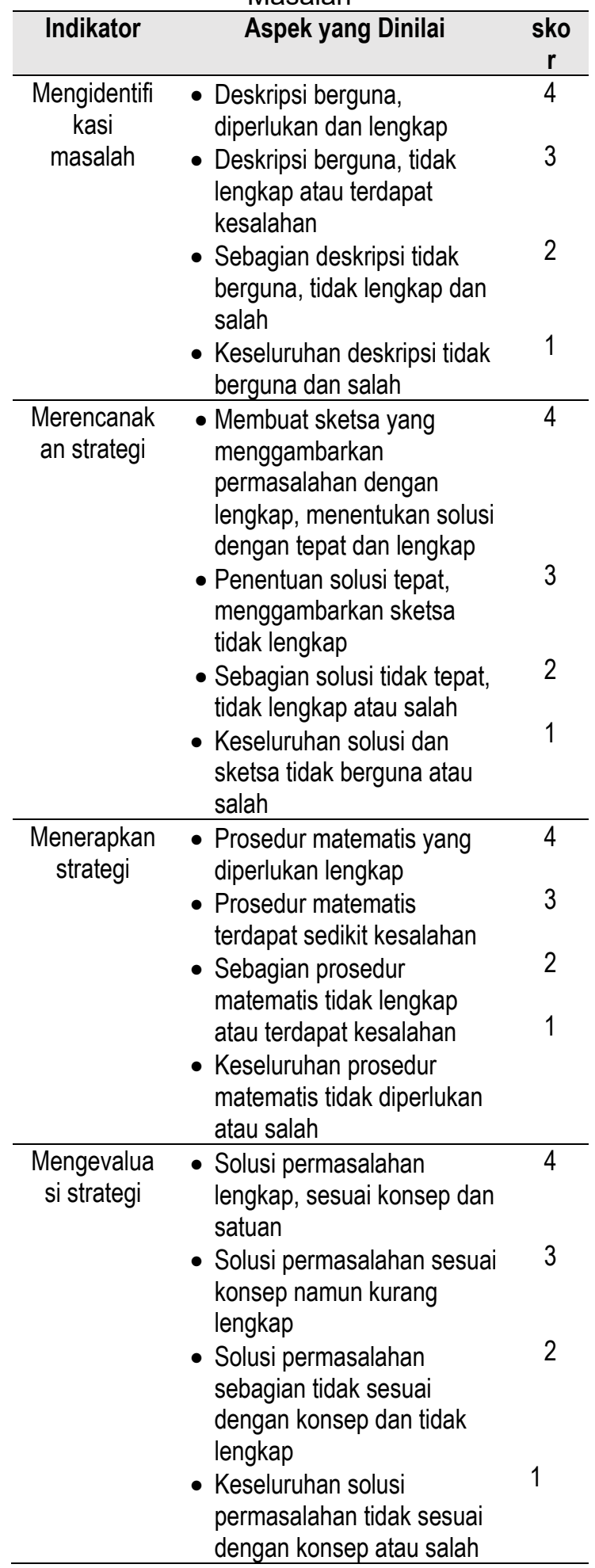

Cara untuk mengetahui skor kemampuan pemecahan masalah digunakan rumus:

$$
\text { skor }=\frac{\text { jumlah skor yang diperoleh }}{\text { skor maksimal }} \times 100 \%
$$

Setelah skor diperoleh, selanjutnya dilakukan analisis dan dikelompokkan dalam 4 ketogori yaitu sangat tinggi, tinggi, rendah dan sangat rendah. kategori kemampuan pemecahan masalah ditunjukkan pada Tabel 2.

Tabel 2. Kategori Kemampuan Pemecahan Masalah

\begin{tabular}{|c|c|}
\hline Persentase (\%) & Kategori \\
\hline $76-100$ & Sangat tinggi \\
\hline $51-75$ & Tinggi \\
\hline $26-50$ & Rendah \\
\hline $0-25$ & Sangat rendah \\
\hline
\end{tabular}

\section{HASIL DAN PEMBAHASAN}

\section{Kemampuan Pemecahan Masalah}

Data hasil tes dilakukan analisis untuk memperoleh gambaran kemampuan pemecahan peserta didik. Analisis hasil tes peserta didik disesuaikan indikator kemampuan pemecahan masalah yaitu mengindentifikasi masalah, merencanakan strategi penyelesaian masalah, menerapkan strategi dan mengevaluasi strategi penyelesaian masalah. Kemampuan pemecahan masalah peserta didik berdasarkan tahapan indikator ditunjukkan pada Tabel 3. Berdasarkan hasil analisis menunjukkan bahwa kemampuan pemecahan peserta didik pada setiap tahapan indikator meningkat.

Tabel 3. Skor Pretest dan Posttest Peserta

Didik Berdasarkan Indikator Pemecahan Masalah

\begin{tabular}{lcc}
\hline \multicolumn{2}{c}{$\begin{array}{c}\text { Indikator Tahapan } \\
\text { Pemecahan Masalah }\end{array}$} & $\begin{array}{c}\text { Skor Tes Rata- } \\
\text { Rata (\%) }\end{array}$ \\
\cline { 2 - 3 } & Pretest & Posttest \\
\hline $\begin{array}{l}\text { Mengidentifikasi } \\
\text { masalah }\end{array}$ & 49 & 63 \\
\hline Merencanakan strategi & 32 & 52 \\
\hline Menerapkan strategi & 48 & 56 \\
\hline Mengevaluasi strategi & 44 & 53 \\
\hline
\end{tabular}

Tahap awal pemecahan masalah, peserta didik diharapkan dapat mengidentifikasi dan menganalisis permasalahan yang dihadapi, sehingga peserta didik mampu memahami masalah yang sebenarnya. Hasil analisis menunjukkan bahwa kemampuan mengidentifikasi masalah peserta didik meningkat dari kategori rendah menjadi tinggi. Peserta didik mampu memberikan deskripsi yang berguna dan diperlukan untuk tahap awal menyelesaikan masalah. Peserta didik membuat catatan informasi penting yang diketahui dan menentukan besaran yang ditanyakan terkait permasalahan. Meskipun mengalami peningkatan, namun terdapat beberapa peserta didik yang masih kesulitan dalam mengidentifikasi masalah. Dilihat dari beberapa peserta didik yang memberikan deskripsi hasil identifikasi tetapi tidak tepat. 
Selain itu, terdapat pula beberapa peserta didik yang tidak memberikan deskripsi apapun untuk membantu dalam memecahkan masalah.

$$
\text { Indikator merencanakan strategi }
$$

penyelesaian masalah, skor rata-rata kemampuan peserta didik meningkat dari kategori rendah menjadi tinggi. Hal ini ditunjukkan peserta didik dapat merancang sebuah strategi seperti membuat skema yang mengambarkan permasalahan dan menentukan solusi yang akan digunakan untuk menyelesaikan masalah. Hal ini karena dalam pembelajaran kelas terbalik berbasis proyek peserta didik dilatih untuk menyelesaikan masalah melalui proyek. Untuk menyelesaikan proyek peserta didik akan melakukan sebuah upaya agar proyek dapat selesai. Peserta didik akan merencanakan strategi atau membuat rencana penyelesaian. Kegiatan tersebut melatih kemampuan peserta didik dalam merencanakan strategi penyelesaian suatu masalah dengan lebih baik.

Menerapkan strategi merupakan kegiatan peserta didik melaksanakan strategi yang telah direncanakan sebelumnya untuk dapat menyelesaikan masalah dengan tepat. Kemampuan menerapkan strategi mengalami peningkatan dari rendah menjadi kategori tinggi. Hal ini ditunjukkan peserta didik mampu menerapkan trategi dengan baik dilihat dari prosedur matematis yang diselesaikan runut dan lengkap. Selain itu, karena dalam tahap awal penyelesaian masalah peserta didik mampu memahami dan merencanakan strategi sehingga memudahkan peserta didik dalam menerapkan strategi. Meskipun demikian, masih ditemukan beberapa peserta didik yang memiliki kemampuan penerapan strategi rendah. Peserta didik tersebut cenderung melaksanakan prosedur yang kurang tepat, mengalami kesulitan pada perhitungan matematis dan kurang memperhatikan satuan yang digunakan. Selain itu karena peserta didik tidak merencanakan dan memahami permasalahan. Hal tersebut berdampak pada indikator selanjutnya, sehingga peserta didik mengalami kebingungan dalam menerapkan konsep. Sesuai dengan Korhasan dan Ozcan (2015) yang mengungkapkan bahwa rendahnya kemampuan peserta didik dalam menggunakan model matematika menyebabkan mereka mengalami kesulitan menentukan konsep yang sesuai. Keterampilan matematika yang buruk dan kurangnya memahami masalah ialah kendala utama dalam damain keterampilan memecahkan masalah fisika (Reddy \& Panacharoensawad, 2017). Indikator mengevaluasi strategi penyelesaian masalah, kemampuan peserta didik meningkat dari kemampuan rendah menjadi tinggi. Peserta didik memeriksa kembali kelengkapan solusi pemecahan masalah dan satuan yang digunakan. Sesuai dengan hasil wawancara bahwa hasil jawaban yang telah dikerjakan dicek kembali. Namun masih ditemukan peserta didik yang tidak melakukan evaluasi strategi. Berdasarkan hasil wawancara, penyebab peserta didik yang tidak mengevaluasi kembali karena merasa kesulitan menghubungkan kesesuaian konsep terhadap hasil penyelesaiannya. Untuk dapat melakukan evaluasi strategi peserta didik harus memahami konsep dengan baik dan mampu menghubungkan antar konsep dengan baik. Oleh karena waktu pertemuan yang singkat, peserta didik belum terbiasa membuat kesimpulan pada pembelajaran sebelumnya sehingga kurang terlatih pada tahap ini.

Jumlah peserta didik yang memiliki kemampuan pemecahan masalah dalam pembelajaran flipped classroom berbasis proyek ditunjukkan pada Tabel 4.

Tabel 4. Persentase Peserta didik dalam Kemampuan Pemecahan Masalah

\begin{tabular}{ccc}
\hline \multirow{2}{*}{ Kategori } & \multicolumn{2}{c}{$\begin{array}{c}\text { Skor Tes Rata-Rata } \\
\text { (\%) }\end{array}$} \\
\cline { 2 - 3 } & Pretest & Posttest \\
\hline Sangat tinggi & 0 & 17 \\
\hline Tinggi & 6 & 45 \\
\hline Rendah & 92 & 38 \\
\hline Sangat rendah & 2 & 0 \\
\hline
\end{tabular}

Berdasarkan Tabel 4. peserta didik memiliki kemampuan pemecahan masalah yang lebih baik dalam pembelajaran flipped classroom berbasis proyek. Hasil pretest $42 \%$ peserta didik memiliki kemampuan pemecahan masalah yang tergolong rendah. Rendahnya kemampun pemecahan masalah peserta didik disebabkan oleh rendahnya kemampuan peserta didik dalam memahami masalah, kurang terlatih dalam menyelesaikan pemecahan masalah. Namun pada hasil posttest $58 \%$ peserta didik memiliki kemampuan pemecahan masalah tinggi. Hal ini ditunjukkan peserta didik mampu mengidentifikasi masalah, mengilustrasikan hingga menyelesaikan masalah dengan benar. Tingginya kemampuan pemecahan masalah karena dalam pembelajaran peserta didik dilatih untuk memahami dan membuat ilustrasi terkait permasalahan. Hal tersebut mempermudah peserta didik untuk memecahkan masalah.

Berdasarkan hasil analisis, diperoleh kesimpulan bahwa peserta didik memiliki kemampuan pemecahan masalah tinggi dalam pembelajaran flipped classroom berbasis proyek. Hal ini karena pembelajaran berbasis proyek menekankan pada kegiatan belajar 
yang kompleks. Pembelajaranya berfokus pada konsep-konsep dan melibatkan peserta didik dalam penyelesaian masalah. Memberikan kesempatan pada peserta didik untuk memperoleh pengetahuan mereka sendiri, dan mencapainya dengan menghasilkan produk. Hasil ini didukung oleh penelitian yang telah dilakukan Dewi et al., (2017) menyatakan bahwa kemampuan pemecahan masalah peserta didik yang menggunakan pembelajaran berbasis proyek lebih baik dibandingkan pembelajaran konvensional. Karina et al., (2014) menyatakan bahwa pembelajaran berbasis proyek dapat mengembangkan kemampuan pemecahan peserta didik.

Sementara itu, pembelajaran flipped classroom dilakukan dengan memberikan bahan literatur yang dibutuhkan dan tugas kepada peserta didik. Di kelas peserta didik melakukan diskusi dan menyelesaikan soal pemecahan masalah. Kelas menjadi lebih hidup dimana peserta didik secara aktif berkomunikasi antar teman dan guru pada saat menyelesaikan latihan yang diberikan. Sejalan dengan hasil penelitian Elmaadaway (2018) bahwa melalui pendekatan flipped classroom, peserta didik mempelajari materi terlebih dahulu di rumah, sehingga di kelas berpartisipasi dengan kegiatan yang relevan, mengajukan pertanyaan dan terlibat dalam pemecahan masalah. Bergfjord (2016) menyatakan bahwa dalam flipped classroom, peserta didik mempersiapkan diri dengan lebih baik untuk pembelajaran di kelas, merasa puas dan mencapai hasil belajar yang lebih baik. Jadi, pembelajaran tersebut mempunyai efek positif terhadap pengetahuan, keterampilan, dan keterlibatan peserta didik (Zamorano et al., 2019). Selain itu, Chiang (2017) juga mendukung hasil penelitian ini bahwa pembelajaran flipped classroom berbasis proyek efektif digunakan dalam pembelajaran. Namun beberapa peserta didik mungkin menjadi terbebani karena akan lebih banyak menghabiskan waktu untuk menonton video dan mengerjakan tugas (Boeve et al., 2017).

\section{Pola Pemecahan Masalah}

Pola pemecahan masalah merupakan langkah-langkah yang dilakukan peserta didik dalam mengatasi masalah. Ditemukan 3 pola pemecahan berdasarkan tingkat kemampuan pemecahan masalah yaitu pola pemecahan masalah pada kemampuan sangat tinggi, tinggi dan rendah.

Pola pemecahan masalah pada kemampuan sangat tinggi disajikan pada Gambar 1.

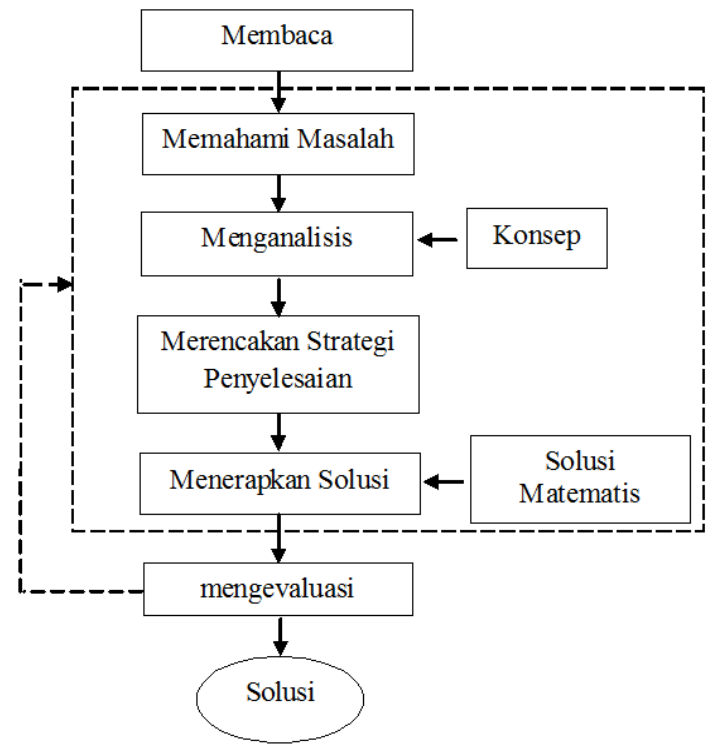

Gambar 1. Pola pemecahan masalah pada kemampuan sangat tinggi.

Berdasarkan Gambar 1. menunjukan bahwa kemampuan peserta didik pada kemampuan sangat tinggi melibatkan semua tahapan pemecahan masalah dari mengidentifikasi masalah hingga melakukan evaluasi. Pada tahap awal peserta didik memahami permasalahan. Dari proses memahami masalah peserta didik melakukan analisis sehingga memperoleh informasi penting atau data awal dan konsep yang berhubungan dengan permasalahan. Selanjutnya, peserta didik melakukan perencanaan penyelesaian dengan mengaitkan beberapa konsep. Membuat skema yang menggambarkan permasalahan kemudian menarik dugaan atas permasalah dan dijadikan dasar untuk menentukan solusi. Setelah menerapkan solusi penyelesaian, peserta didik melakukan evaluasi dengan mengecek kembali atas solusi yang telah ditentukan. Berikut ini penggalan wawancara terhadap responden yang memiliki kemampuan pemecahan masalah sangat tinggi.

PD-1 :Saya baca dulu bu, setelah saya pahami, lalu saya ditulis yang diketahui sama yang ditanyakan.

P :Selanjutnya?

PD-1 : Saya kerjakan sesuai apa yang saya tahu bu. Kayaknya pernah ngerjain soal yang rada mirip seperti soal itu bu.

P :Ok. Kalau no 2 menurut anda apa permasalahannya?

PD-1 : (Melihat soal) ada satu pegas di beri gaya bertambah panjang $8 \mathrm{~cm}$. terus pegas itu di potong jadi 3 , yang ditanyakan gaya yang harus diberikan pada bagian pegas agar panjang $4 \mathrm{~cm}$ ?

$\mathrm{P} \quad$ : Bagian pegas? 
PD-1 : Maksudnya satu pegas yang sudah di potong bu. Kayak gambar yang saya buat ini bu (menunjuk jawaban)

P :Apakah nilai konstanta pada pegas pertama dengan 1 bagian pegas ini sama?

PD-1 :Tidak bu, soalnya kan sudah di potong jadi tiga. Jadi setiap bagianya ya satu di bagi 3 bu, pagas pertama 1 dan 1 bagian pegas yang sudah di potong sepertiga, bener ga bu.

$\mathrm{P} \quad$ :Jadi 1 bagian pegas nilai kosntantanya $1 / 3$ ?

PD-1 : lya bu.

$\mathrm{P} \quad$ :Setelah selesai menjawab, apakah anda mengecek jawabannya kembali?

PD-1 :Tergantung bu, kalau waktunya belum habis ya saya cek. Kemaren saya cuman ngecek no 1 aj bu, karena waktunya sudah habis.

P :Anda mengeceknya sekedar dilihat sekilas atau?

PD-1 :Ya dari yang diketahui bu sampai bawah, sama satuannya juga.

Peserta didik dengan kemampuan pemecahan masalah sangat tinggi dapat melibatkan konsep yang sesuai dalam proses penyelesaian masalah. Hal tersebut membuat peserta didik dapat menyelesaikan permasalahan dengan mudah. Pada tes kemampuan pemecahan masalah responden PD-1 memberikan analisis yang cukup baik terhadap permasalah yang diberikan. Responden PD-1 mengaitkan konsep berdasarkan hasil analisinya dan mengilustrasikan dengan membuat bagan permasalahan. Berdasarkan hasil wawancara, responden PD-1 melakukan pengecekan ulang setelah selesai mengerjakan soal.

Sama halnya dengan peserta didik yang memiliki kemampuan pemecahan masalah sangat tinggi, peserta didik yang memiliki kemampuan pemecahan masalah tinggi, memulai proses pemecahan masalah dengan memahami permasalahan. Pola pemecahan masalah peserta didik dengan kemampuan tinggi disajikan pada Gambar 2.

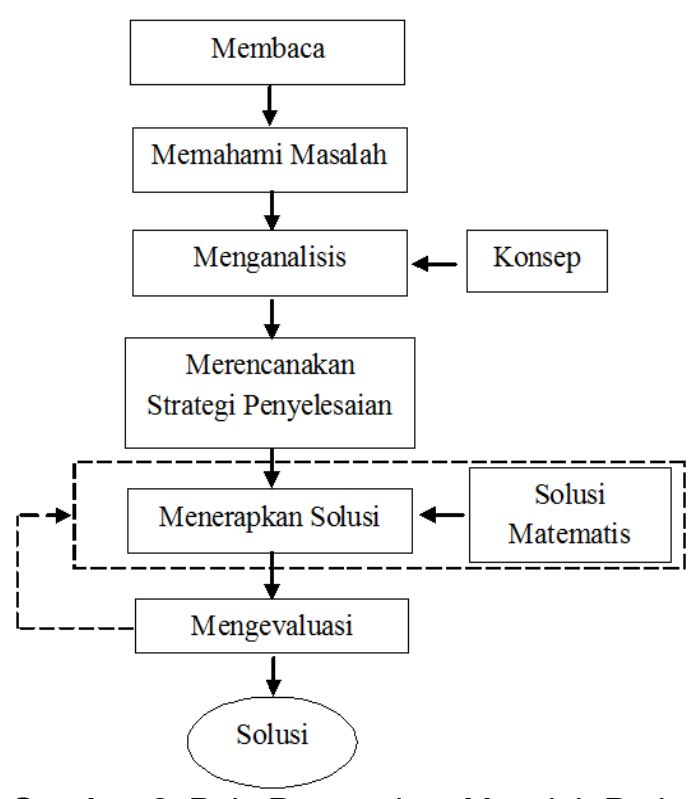

Gambar 2. Pola Pemecahan Masalah Pada Kemampuan Tinggi.

Peserta didik melakukan analisis untuk memperoleh informasi penting. Selanjutnya, melakukan perencanaan penyelesaian dengan mengaitkan beberapa konsep. Berikut ini penggalan wawancara terhadap responden yang memiliki kemampuan pemecahan masalah tinggi.

PD-3 :Ya sama bu, ini pegasnya saya gambar dulu biar jelas soalnya kan dipotong potong. Itu kemaren saya rada bingung bu, jadi nanya-nanya temen.

$P \quad$ : Bingung tidak paham soalnya?

PD-2 :Nggak pernah ngerjain yang pakai huruf gitu bu, biasanya kan gaya di ketahui berapa gitu bu, kalau inikan nggk.

P : :(Menunjuk jawaban), tolong jelaskan jawaban anda?

PD-2 :Gini bu, itukan satu pegas dipotong jadi tiga jadi ya kontantanya bagi tiga bu, trus dimasukin ke rumus $\mathrm{k}$ kali detla $\mathrm{x}$. Kata temenku gitu bu

P :Jadi sebenarnya anda tidak bisa menyelesaikan soal no 2 ?

PD-2 :Tanya caranya aja bu, trus saya kerjain sendiri kok bu, beneran.

P : :Ok. Setelah selesai menjawab, apakah anda mengecek jawabannya kembali?

PD-2 : Ada yang nggak ada yang iya.

$\mathrm{P} \quad$ :Anda mengeceknya sekedar dilihat sekilas atau bagaimana?

PD-2 :Kemaren saya hanya cek no 1, liat perhitungannya bu, waktunya juga sudah abis.

Peserta didik yang tergolong kemampuan tinggi belum memahami konsep dengan baik sehingga berpengaruh terhadap 
jawabannya. Peserta didik kemudian melaksanakan solusi dan melakukan evaluasi terhadap solusi. Namun evaluasi dilakukan hanya pada perhitungan matematis. Peserta didik tidak melakukan evaluasi dari awal permasalahan. Hal tersebut karena kurangnya kemampuan peserta didik dalam perencanaan strategi, mengidentifikasi masalah sehingga mempengaruhi kemampuan evaluasinya.

Sementara itu, peserta didik yang tergolong dalam kemampuan pemecahan masalah rendah, melakukan proses pemecahan masalah dengan sederhana. Proses penyelesaian masalah peserta didik yang tergolong kemampuan pemecahan masalah rendah disajikan pada Gambar 3.

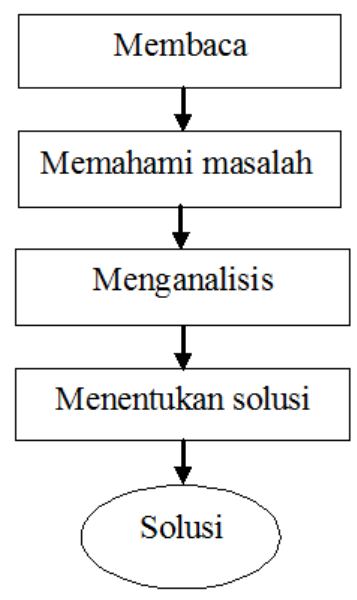

Gambar 3. Pola Pemecahan Masalah Pada Kemampuan Rendah.

Pada proses pemecahan masalah pada kemampuan rendah peserta didik akan memulai dengan membaca, memahami permasalahan. Setelah mencoba memahami permasalahan peserta didik akan melakukan analisis untuk memperoleh data awal yang akan digunakan untuk menentukan solusi.

P : Menurut anda ada berapa cara untuk menyelesaikan permasalah itu?

PD-5 : Nggak tau bu.

$P \quad$ :Ini jawaban anda (menunjuk jawaban)

PD-5 :Feeling bu. Saya ngerjain sendiri loh bu.

P :Apakah setelah membaca soal yang anda peroleh hanya data ini (menunjuk jawaban)?

PD-3 :Ada yang lupa simbol-simbolnya, jadi tidak saya tulis bu hehe.

P :Untuk soal no 4 bagaimana anda menyelesaikannya?

PD-3 :Yang ditanya kan apakah kawat patah kalau ditarik dengan gaya sebesar itu (menunjuk soal), tinggal bandingin saja. Jadi Jawabannya kawat patah bu.

$\mathrm{P} \quad$ :Membandingkan apa dengan apa?
PD-3 :Bentar bu, kemaren saya tanya-tanya temen.Tegangan patah dengan gaya tariknya.

P :Benar dengan gaya tariknya (menunjuk jawaban)?

PD-3 :Eh salah bu (melihat jawaban). tegangan tarik bu.

P :Apakah anda mengecek kembali jawaban anda?

PD-3 :Nggak bu. Waktunya sudah habis kemaren.

Peserta didik melaksanakan penyelesaian dengan mengingat kembali pemahaman yang telah didapakan seblumnya. Peserta didik tidak melakukan evaluasi terhadap solusi yang telah dikerjakan. Hal tersebut karena peserta didik kesulitan untuk memahami permasalahan dan mengaitkannya terhadap konsep yang sesuai/ tepat.

Setiap peserta didik memiliki cara yang berbeda beda dalam menyelesaikan masalah. Peserta didik melakukan proses penyelesaian masalah berdasarkan perkembangannya (Julianti et al., 2013). Selain itu, tingkat kemampuan peserta didik dalam pemecahan masalah juga mempengaruhi proses penyelesaian yang dilakukan. Peserta didik dengan kemampuan pemecahan masalah rendah akan lebih sederhana dalam melakukan proses penyelesaian masalah. berbeda dengan kemampuan tinggi yang melakukan proses penyelesian dengan lebih kompleks. Hasil yang diperoleh dalam penelitian ini sejalan dengan pola pemecahan Polya (1971). Hal ini karena peserta didik dalam penyelsaian pemecahan masalah kecenderungan dalam representasi simbolik.

\section{SIMPULAN}

Berdasarkan hasil penelitian dan pembahasan, diperoleh kesimpulan sebagai berikut:

1. Kemampuan pemecahan masalah peserta didik dalam pembelajaran flipped classroom berbasis proyek tergolong tinggi dengan jumlah peserta didik $57 \%$. Hal ini ditunjukkan peserta didik mampu mengidentifikasi masalah, mengilustrasikan hingga menyelesaikan masalah dengan benar. Tingginya kemampuan pemecahan masalah peserta didik karena dalam pembelajaran peserta didik dilatih untuk memahami dan membuat ilustrasi terkait permasalahan. Hal tersebut mempermudah peserta didik untuk memecahkan masalah.

2. Peserta didik dengan kemampuan pemecahan masalah sangat tinggi, tinggi dan rendah memiliki langkah penyelesaian pemecahan masalah yang berbdeda-beda. 
Peserta didik kategori sangat tinggi melakukan penyelesaian dengan membaca, memahami masalah, menganalisis, merencanakan strategi penyelesaian, menerapkan dan mengevaluasi seluruh solusi. Peserta didik kategori tinggi melakukan penyelesaian dengan membaca, memahami masalah, menganalisis, merencanakan strategi penyelesaian, menerapkan dan mengevaluasi solusi matematis. Peserta didik kategori rendah melakukan penyelesaian dengan membaca, memahami masalah, menganalisis, menetukan masalah.

\section{DAFTAR RUJUKAN}

Alberida, H., Lufri, Festiyed, \& E Barlian. (2018). Problem Solving Model for Science Learning. IOP Conf. Series: Materials Science and Engineering, 335 012084, 1-13.

Anderson, J. (2009). Mathematics Curriculum Development and the Role of Problem Solving. ACSA Conference, 1-8.

Bergfjord, O.J,(2016). Evaluation of a "Flipped Classroom" Approach in Management Education. Journal of University Teaching \& Learning Practice, 13(5), 1-15.

Bishop, J. \& Verieger, M.A. (2013). Flipped Classroom: A Survey of the Research. 210th ASEE annual Conference \& Explosition, 6219,118.

Boeve, A.J., Meijer, R.R., Bosker, R.J., Vugteveen , J., Hoekstra, R., \& Albers, C.J. (2017). Implementing The Flipped Classroom: An Exploration Of Study Behaviour and Student Performance. High Educ, 74,1015-1032.

Chen, C.H \& Yang, Y.C. (2019). Revisiting the Effect Of Project Based Learning On Students Academic Archievement: A meta-Analysis Investigating Moderator. Education Research And Review, 5(26), 71-81

Chiang, T.H.C. (2017). Analysis of learning behavior in a flipped programing classroom adopting problem-solving strategies. Interactive Learning Environments,25(2), 189-202.

Deng, J. (2018). The Project-Based Flipped Learning Model in Business English Translation Course: Learning, Teaching and Assessment. English Language Teaching, 11(9), 118-128

Dewi, B. M.M., N Khoiri1, N., \& U Kaltsum, U. (2017). Peningkatan Kemampuan
Pemecahan Masalah Siswa Melalui Penerapan Model Project Based Learning. Jurnal Penelitian Pembelajaran Fisika, 8(1), 8-13.

Efstratia, D. (2014). Experiential Education Through Project Based Learning. Procedia-Social and Behavioral Sciences, 152, $1256-1260$.

Elmaadaway, M.A.N. (2017). The Effects Of A Flipped Classroom Approach On Class Engagement and Skill Performance In A Blackboard Course. British Journal of Educational Technology, 1-13.

Erinosho, S.Y. (2013). How Do Students Perceive the Difficulty of Physics in Secondary School? An Exploratory Study in Nigeria. International Journal for Cross Disciplinary Subjects in Education (IJCDSE), 3(3), 1510-1515.

Gaughan, J. E. (2014). The Flipped Classroom in World History. The History Teacher, 47(2), 221-244.

Ge, X. \& Land, S.M. (2004). A Conceptual Framework for Scaffolding IIIStructured Problem Solving Processess Using Question Prompts and Peer Interactions. ETR\&D, 52(2), 5-22

Ince, E. (2018). An Overview of Problem Solving Studies in Physics Education. Journal of Education and Learning, 7(4),191-200.

Julianto, E., Nugroho, S.E., \& Marwoto,P. (2013). Perkembangan pola pemecahan masalah masalah anak usia sekolah dalam memecahkan permasalahan ilmu pengetahuan alam. jurnal pendidikan fisika indonesia, 9, 151-162.

Karina, N.K.D., Sadia, I.W., \& Suastra, I.W. (2014). Pengaruh Model Pembelajaran Berbasis Proyek terhadap Kemampuan Pemecahan Masalah dan Kecerdasan Emosional Siswa SMP. E-Journal Program Pascasarjana Universitas Pendidikan Ganesha Program Studi IPA, 4,1-10.

Kaya, H, senyuva, E., isik, B., \& bodur, G. (2014). Nursing Students Opinions Regarding Project Based Learning. Procedia-Sosial and Behavioral Sciences ,5(157),379-385.

Korhasan, N.D \& Ozcan, O. (2015). Examination of the Variation in Students' Problem Solving Approaches Due to the Use of Mathematical Models in Doppler 
Effect, Hacettepe Universitesi Egitim Fakultesi Dergisi (H. U. Journal of Education), 30(3), 87-101.

Mohhotalla, E. (2016). Improving Critical Using Wikis and GGPS in a Physics Classroom. American Association Of Physisc Teachers, 5(1), 427-429.

Nikat, R.F, parno P. \& Eny L. (2017). Profil Kemampuan Pemecahan Masalah Peserta Didik Pada Materi Usaha dan Energi. Prossiding Seminar pend. Ipa pascasarjana UM, 2, 271277.

Nouri, J. (2016). The Flipped Classroom: For Active, Effective and Increased Learning Especially For Low Achievers. International Journal of Educational Technology in Higher Education, 13(33), 1-10.

Polya, G. (1971). How To Solve It. Second Edition. New Jersey: Princeton University Press.

Purnamasari, I., Yuliati, L., \& Diantoro, M. (2017). Analisis Kemampuan Pemecahan Masalah Fisika pada Materi Fluida Statis. Prossiding Seminar Pend. IPA Pascasarjana UM , 2,191-195.

Purwanto, R., Parno, \& Yuliati, L. (2017). Eksplorasi Kemampuan Pemecahan Masalah Siswa SMA pada Materi Fluida Statis. Pros. Seminar Pend. IPA Pascasarjana UM, 2, 286-292.

Putra, H.D. Putri, W.A.S., Fitriana, U., \& Andayani, F. (2018). Kemampuan Pemecahan Masalah Matematis dan Self-Confidence Siswa SMP . SJME (Supremum Journal of Mathematics Education), 2(2),60-70.

Quint, J \& Condliffe, B. (2018). Project Based Learning A Promising Approach to Improving Student Outcomes. Mdrc Issue Focus, 1-2.

Reddy, M.V.B \& Panacharoensawad, B. (2017). Students Problem-Solving Difficulties and Implications in Physics: An Empirical Study on Influencing Factors. Journal of Education and Practice, 8(14), 5962.

Rivai, H.P., Lia Yuliati, L., \& Parno, P. (2017). Eksplorasi Kemampuan Pemecahan Masalah Konseptual Fluida Dinamis pada Siswa SMA. Pros. Seminar Pend. Ipa Pascasarjana UM, 2,178-184

Sattizahn, J.R., Lyons, D.J., Kontra, Fischer,C.S.M \& Beilock, S.L. (2015). In Physics Education,
Percepion Matters. International Mind, Brain, and Education Society and Wiley Periodicals, 9(3), 164-169.

Tirtarahardja \& Sulo. (2010). Pengantar Pendidikan. Jakarta: Rienka Cipta.

Yulietri, F., Mulyoto, \& Agung, L.S. (2015). Model Flipped Classroom dan Discovery Learning Pengaruhnya terhadap Prestasi Belajar Matematika Ditinjau dari Kemandirian Belajar. Teknodika, 13(2), 5-17.

Zamorano, L.R., Sanchez, J.A.L., \& Caballero, A.L.G. (2019). How The Flipped Classroom Affects Knowledge, Skills, and Engagement In Higher Education: Effects On Students' Satisfaction. Computers \& Education, 141,1-18. 